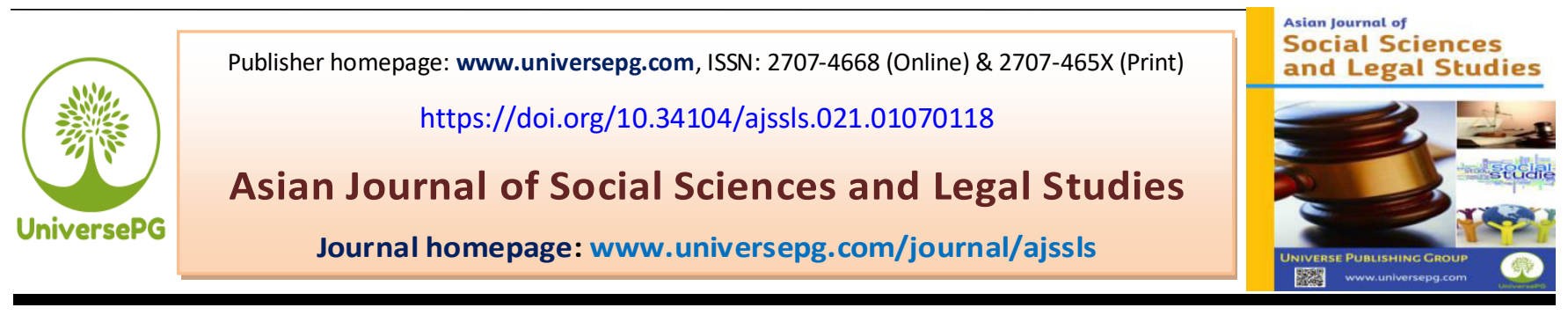

\title{
Identifying Cyclone Shelter Facilities and Limitations for Enhancing Community Resiliency in Coastal Areas of Bangladesh
}

\author{
Most. Nusrat Binte Nur ${ }^{1}$, Md. Abdur Rahim ${ }^{1}$ and Md. Rasheduzzaman ${ }^{2}$ \\ ${ }^{1}$ Dept. of Disaster Resilience and Engineering, Faculty of Environmental Science and Disaster Management, Patuakhali \\ Science and Technology University (PSTU), Dumki, Patuakhali-8602, Bangladesh and ${ }^{2}$ Dept. of Emergency Management, \\ Faculty of Environmental Science and Disaster Management, Patuakhali Science and Technology University (PSTU), \\ Dumki, Patuakhali-8602, Bangladesh. \\ *Correspondence: nusratdre@ pstu.ac.bd (Most. Nusrat Binte Nur, Lecturer, Dept. of Disaster Resilience and Engineering, \\ Faculty of Environmental Science and Disaster Management, PSTU, Dumki, Patuakhali-8602, Bangladesh).
}

\begin{abstract}
Amtali is a vulnerable coastal Upazila in the Barguna district of Bangladesh. It is more vulnerable to cyclone disasters. The devastating cyclone is frequently a phenomenon here. Cyclone shelter is a structural measure to decrease cyclone vulnerabilities. The main purpose of this study is to identify facilities and problems of the cyclone shelter from the people's perceptions of the study space. To accomplish the aim, a semi-structured, household questionnaire (100 individual responses) survey is used. Besides ten key informer interviews are also used to authenticate the collected information. The key findings of these lessons are insufficient shelter facilities (65\% opined), unhealthy sanitation, scarcity of safe drinking water, inadequate medical facilities, limited or almost no facilities for women, especially for pregnant women. Overall facilities are not enough for the public. Perception shows that women are more vulnerable due to improper management of shelter including harassment. Many types of limitations are found in the shelters. For those reasons, individuals don't seem to be interested to travel to cyclone shelters. Proper early warning as well as informat on dissemination systems are not well developed and not properly working in due times. About $70 \%$ of respondent's viewed that the supervision method of cyclone shelters is unhealthy, unhygienic, and unsatisfactory levels. For enhancing people's encouragement and participation to go to cyclone shelters, healthy sanitation, safe beverage provides, proper medical facilities, separate rooms, and bogs for women must be needed to build the community more resilient. Sufficient and frequent training on cyclone shelter usability and management, communities early warning understanding and reception, awareness-raising programs, and proper information on disaster management should be strengthened for enhancing community resiliency to cyclonic disasters.
\end{abstract}

Keywords: Cyclone shelter, Community resiliency, Limitations, Facilities, Identifying, and Coastal areas.

\section{INTRODUCTION:}

Due to geo graphical and regional location, Bangladesh is widely measured to be one amongst the foremost climate exposed countries in the world which also has a very high population density (Nasreen et al., 2013). The southern region of Bangladesh is at extUniversePG I www.universepg.com reme risk of climate induced disasters such as cyclones and storm surges, water level rise and river bank erosion (Obaidullah et al., 2014). Among these disasters, cyclone is taken into account because the major and most devastating disaster to the human habitation of this country. Bangladesh is a universal place for tro- 
pical cyclones (Dasgupta et al., 2014). During the last a hundred years, Asian country has old fifty-three major cyclones (Ahamed et al., 2012). Some of the devastating cyclones that hit Bangladesh coast are in year 1970, 1991, 1997, and 2007. Many people are died in these cyclone disasters. Storm surges heights are almost $10 \mathrm{~m}, 7.6 \mathrm{~m}, 4.55 \mathrm{~m}, 6 \mathrm{~m}$ in the time cyclonic disasters (Choudhury, 2014).

Bangladesh is vulnerable to periodic natural disasters especially cyclones (Hasan, 2008). Structural and nonstructural measures can decrease the cyclone vulnerability (Karim, 2006). One of the foremost recognizable policies to cut back risk of cyclone is cyclone shelter (Amin et al., 2016). Enough cyclone shelters are required to reduce the susceptibility of the community living within the coastal region. Location also is considered to reduce the disasters vulnerability. Spatial planning for cyclone shelters can also minimize the susceptibility of the community (Tamima, 2009). There are several cyclone shelters within the coastal areas of the country, however existing shelter range is kind of tiny instead of population. New multi-purpose cyclone shelter amenities are needed in Bangladesh (Mahmood et al., 2014). Its amenities and situation were poorer rather than people expectation (Ahmed, 2010). To ensure the safer shelter of the coastal community and people living in the vulnerable flood prone areas, the Government has already constructed 2033 numbers of cyclone and flood shelters. But it should realize that due to increase the amount of population and the cattle heads, it's become essential to construct additional 2000 numbers of disaster shelters within the coastal areas (DMB, 2010).

The environment of the cyclone shelters is not found gender-friendly in Bangladesh (Chowdhury et al., 2015). Cyclone shelters facilities are a considerable issue for increasing people's rate about go to cyclone shelter. Amtali upazila, Barguna is one of the foremost vulnerable areas to cyclone disasters. Every year devastating cyclones occur in this region. Peoples are not attracted to travel to cyclone shelters because of many problems in cyclone shelter. Facilities and limitations are not well established within the past research. Early warning dissemination system and understanding level of warning is a consider factor in this lesson. Many people are not able to receive warning. People within the coastal areas do not follow the evacuation orders due to mistrust of the warning messages (Roy et al., 2015).

In this area the number of cyclone shelter is not enough than population. Management system of cyclone shelter is not well during this space. Moreover, the facilities of these Coughs to be improved that encourage a lot of individuals to come back throughout disaster scenario. This lesson is designed to identifying the facilities and problems of cyclone shelters, situation of the cyclone shelter management system, and early warning method of the study region. Government of Bangladesh can be taken necessary steps to reduce the problems.

\section{Objectives of the study}

1) To find out the facilities and problems of cyclone shelter

2) To know about early warning systems in study area

3) To know about management system of cyclone shelter

\section{METHOLODOGY:}

3.1 Study area - For this study, Amtali upazila in Barguna district was selected. Kukua and Chawra Union under Amtali upazila selected as the study region. Amtali upazila is situated in the southern area. Many devastating cyclones were occurred here. This region is susceptible to expected disaster. Cyclone shelters are not sufficient there. People face many problems when they stay within the cyclone shelter within the time of cyclone. Amenities of cyclone shelter are negligible in this region.

The upazila occupies an area of 720.75 sq.km of which 51.64 sq. $\mathrm{km}$ is under forest. It is located between $21^{\circ} 51^{\prime}$ and $22^{\circ} 18^{\prime}$ north latitudes and between $90^{\circ} 00^{\prime}$ and $90^{\circ} 23^{\prime}$ east longitudes. The upazila is surrounded on the north near Patuakhali sadar upazila of Patuakhali zila, east by Galachipa upazila and Kalapara upazila of Patuakhali zila, south near the Bay of Bengal as well as west by Mirzaganj upazila of Patuakhali zila and Barguna sadar upazila. The upazila consists of 1 paurashava, 9 wards, 14 mahallas, 14 unions, 68 populated mauzas and 184 villages (BBS Community report, 2011). 

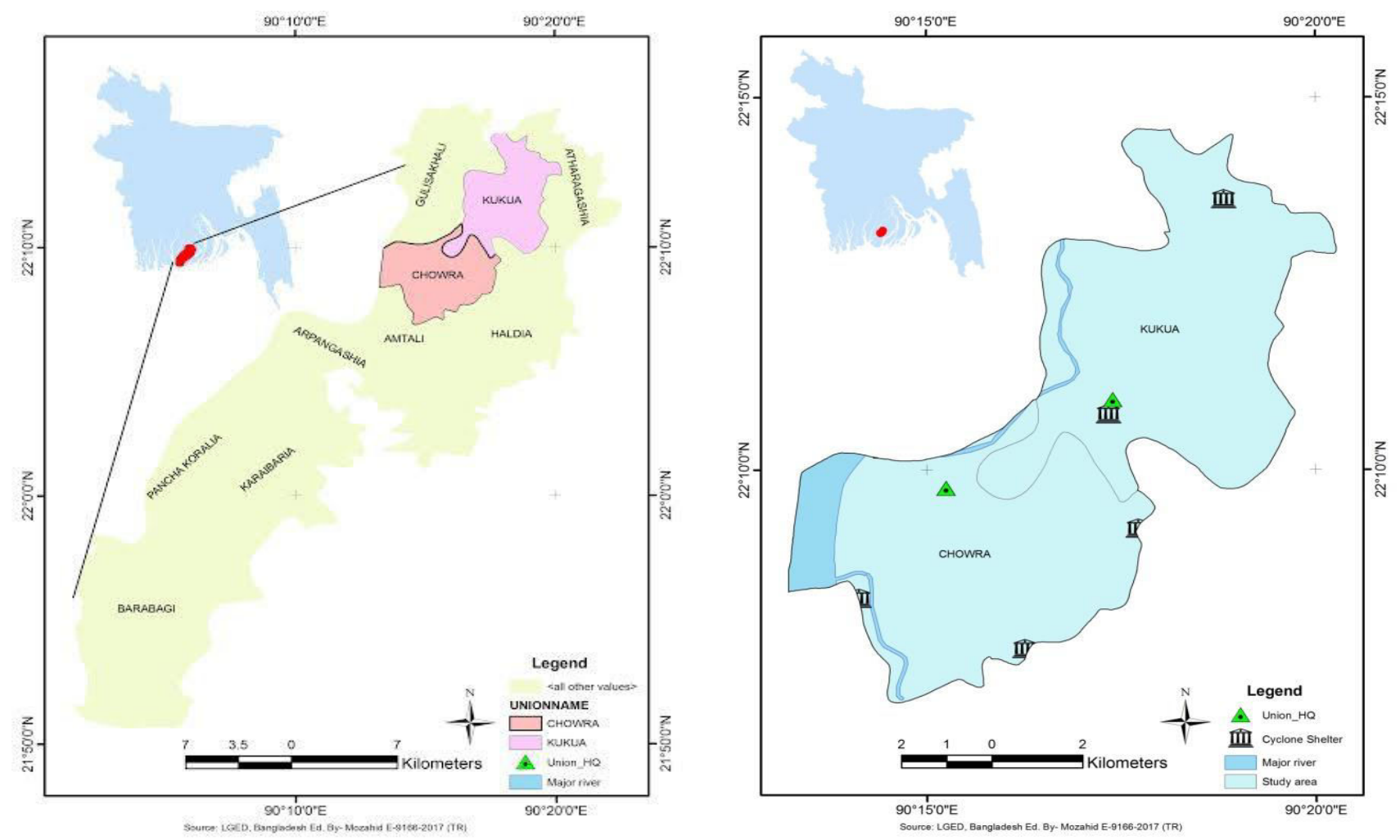

Fig 1: Position of the study region and location of cyclone shelter.

3.2 Applied methodology - It is vital to possess valid method to conduct a study. The authors have utilized equally qualitative and quantitative strategy to accomplish objectives of this research. To begin with, qualitative analysis involve 100 household survey at $95 \%$ confidence level. On the other hand, quantitative analysis have been diagnosed with Microsoft excel data analysis software. Moreover, the stuy area map is prepared by the help of Arc GIS 10.5. Finally, sample size calculation equation reveals in equation (i).

Sample size calculation equation is elucidating by -

$$
\eta=\sqrt{\frac{(1.96 \times \sigma)}{P}}
$$

Where, $\sigma=$ standard deviation, $\eta=$ sample size, $\mathrm{P}=$ proportion to be estimated $=0.5, \mathrm{t}=1.96$ at $95 \%$ confidence level.

Secondary data was collected for a brief literature review. The secondary data was collected on various aspects related to the natural hazards specially cyclone, cyclone shelter facilities, early warning system,climate change and impacts in the coastalregion was done through literature review of books, journals, newpaper, BBS report (Rasheduzzaman et al., 2020).

\section{RESULT AND DISCUSSION:}

4.1 Respondent profile - Amtali upazila is vulnerable for cyclone disaster. Every year many cyclones are occurred here. In the time of cyclone people are take shelter in the cyclone shelter. The community of the Kukua union and Chawra Union under Amtali upazila are faced many cyclones in their living period in this spot. The study areas are vulnerable for cyclone disaster because it is near about the Bay of Bengal besides Buriswar River is also near about the area. Household form investigation was conduct with two unions wherever total respondent no is one hundred. Out of the overall respondents in the lessons area approximately $45 \%$ were males and $55 \%$ were females.

4.2 Availability of cyclone shelter - Within the study area shelter is not sufficient rather than population. Position of cyclone shelter is not suitable for the people. People are realized cyclone shelter is needed in their area. Within the study region about $35 \%$ people said that cyclone shelters are available in their area. More than 1/2of the people (65\%) said that cyclone shelters are not available in their area. Available cyclone shelter needs to be established for the people. 
4.3 Distance of nearby shelter from the house Distance is the fact to go to cyclone shelter in due time. People said they could not reach cyclone shelter because of long distance. They face many problems in the road. The most important reason why individuals are not interested to travel to cyclone shelter is distance of nearby shelter from the house (Fig 2).

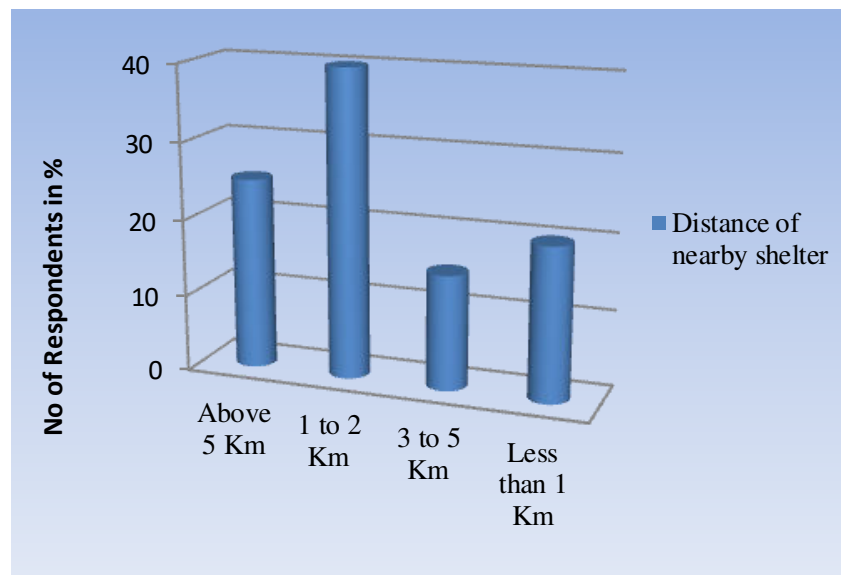

Fig 2: Distance of nearby shelter (Field Survey-2018).

From the Fig 2 about distance of nearby shelter about $25 \%$ people said cyclone shelter is situated above 5 $\mathrm{km}$ from their house. About $40 \%$ people said cyclone shelter is situated 1 to $2 \mathrm{~km}$ from their house. Almost $15 \%$ said cyclone shelter is situated 3 to $5 \mathrm{~km}$ from their house. Only $20 \%$ people said that cyclone shelter is situated near about their house. The distance of this shelter is more than one to two kilometers from the village. Because the shelters area unit secluded from the village the folks don't seem to be willing to travel to the present shelter. People realized; Long distance is the reason for decreasing the rate of interested people about go to cyclone shelter.

\subsection{Percentage of interested people about goes to} cyclone shelter - Household head stay at home to protect the property. They try to send people to shelter, but all family units not interested to travel to shelter. Insufficient accommodation capacity of the nearest cyclone shelter was also a reason for not interested to travel to cyclone shelter. No of interested people are very less rather than total population. From the field survey, now days about $40 \%$ public are not interested to travel to cyclone shelter and $60 \%$ people are interested to travel to cyclone shelter. These peoples are also said facilities are not good there. So, they do not interest to go to cyclone shelter. Some people think, home is better than cyclone shelter. Inaccessible road condition is also an obstacle to go to cyclone shelter. Among the $40 \%$ people, maximum people do not go to shelters because of security in the cyclonic period.

4.5 Capacity level of Cyclone shelter - From the people perception and BBS report it is clear that, Capacity of cyclone shelter is very low (Fig 3). No of shelter is very short rather than population. In study area housing condition is not well.

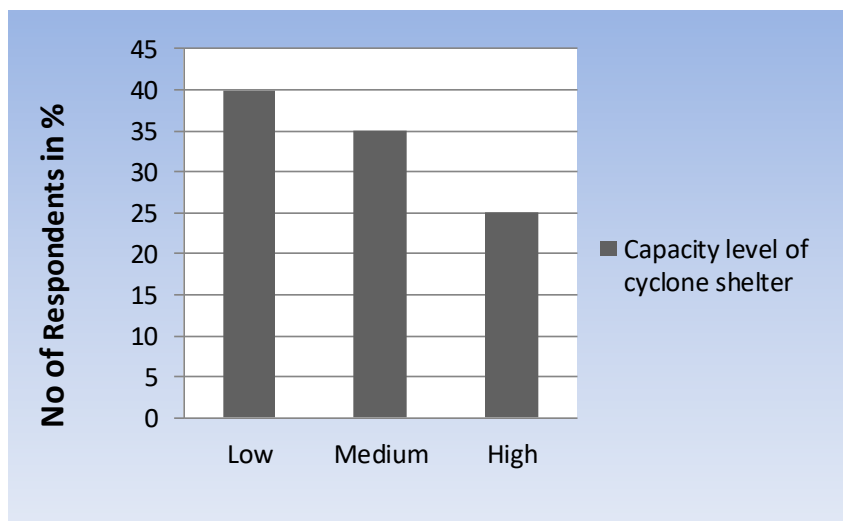

Fig 3: Capacity level of cyclone shelter (Field Survey2018).

Only about $25 \%$ people said capacity level of cyclone is high. They think in the time of cyclone they must be take all members within the shelter. About $40 \%$ people of study area realized they do not take all family members within the shelter because the capacity level is very low. Room is not enough for all peoples. Almost $35 \%$ people said capacity level of cyclone asylum is medium. Increasing no of cyclone asylum is a concern issue for enhancing capacity level of cyclone shelter. Capacity level must be considered to build a new construction of cyclone asylum.

\subsection{Possibility about reached to cyclone shelter -} Communication network especially the road network is a vital factor about reached to cyclone shelter. In the region wherever there is no proper road network, people face great problem to cross even a small distance during the time of cyclone. Many people's are not each within the shelter in due time. In study area $69 \%$ people said it is rough to achieve cyclone shelter in due time. Road construction is not good. Electric wire is a problem of this area during cyclone. In the moment of 
cyclone, water level is high so public are not able to swim. Communication problem is also an obstacle for peoples to arrive at cyclone shelter in due time. Only $31 \%$ people said it is easy for them to arrive at cyclone shelter in due time. It is additionally found that people do not prefer to cross water way especially during the night of disaster.

\subsection{Sanitation facilities in the cyclone shelter - From} the field survey it is found that of the toilets are situated on ground floor and they are separate from the shelter. These toilets are not usable during disaster as most of them are flooded under flood water. Sanitation facilities of the cyclone shelters were a great deal insanitary (Fig 4).

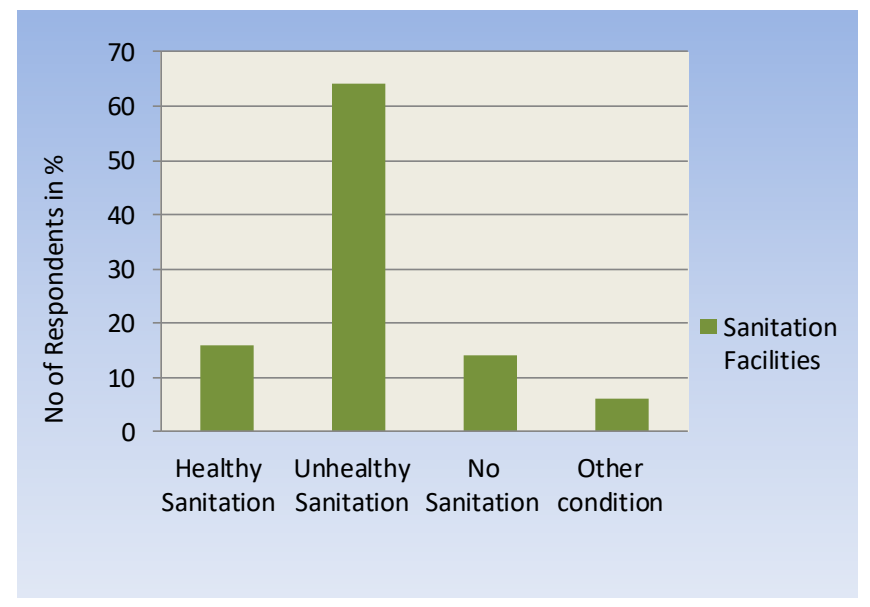

Fig 4: Sanitation facilities in the cyclone shelter (Field Survey-2018).

Around $16 \%$ respondents realized healthy sanitation within the cyclone shelter and regarding $64 \%$ respondents said insanitary sanitation in the cyclone shelters. Moreover, about $14 \%$ of the respondents observed no hygiene services in the cyclone shelters as well as about $6 \%$ people said about other condition of the cyclone shelters. For the betterment of people sanitation facilities must be considered. When sanitation services of the cyclone shelter are not hygienic that time people are sufferer from many diseases. They are not attracted to stay in the cyclone shelter.

\subsection{Drinking water facilities in the cyclone shelter -}

Water supply facilities of the cyclone shelters were insufficient relative to the opposite facilities within the cyclone shelter (Fig 5). Water is an essential element for all people. But drinking water facilities were not sufficient within the cyclone shelter.

UniversePG I www.universepg.com

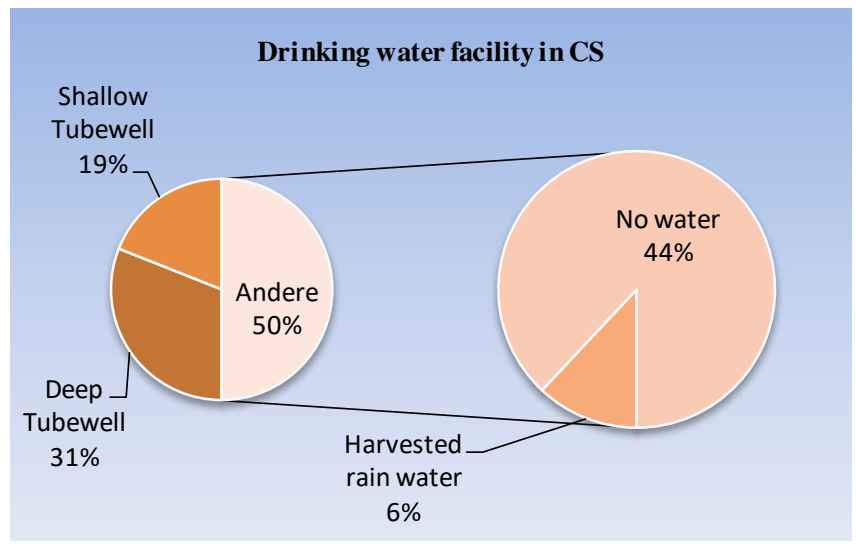

Fig 5: Drinking water facilities in the cyclone shelter (Field Survey-2018).

Around $31 \%$ of the water provides within the cyclone shelter were from deep driven well and 19\% water system was from shallow driven well. On the other hand, more than $44 \%$ of the cyclone shelter had no water facilities. $6 \%$ of the water provide on cyclone shelter was from rainwater harvest. These eventualities showed the water deficiency throughout disaster scenario. $6 \%$ of the water supply on the cyclone by rain water gathering depend only nature. Rain water harvest is the only source of water in the area where no water facilities within the cyclone shelter. Public of the study area said, when any disaster occurred that time nearly all of the tube well are not use. Alternative source of drinking water must be needed within the shelter.

4.9 Medical facilities in the cyclone shelter - During cyclone people faced many problems. Injury was one of them. In the study region medical facilities were not fine within the cyclone shelter (Fig 6). Medical facilities of the cyclone shelters were extremely negligible rather than people requirement.

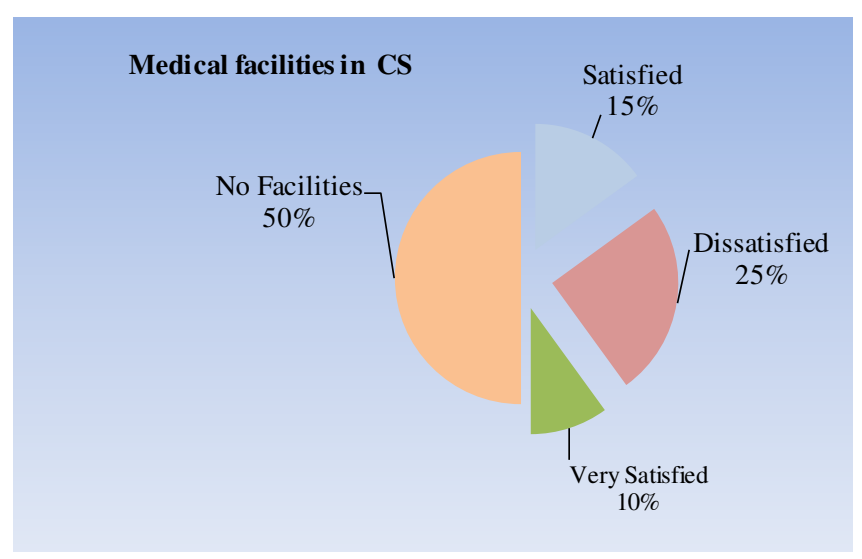

Fig 6: Medical facilities within the cyclone shelter (Field Survey-2018). 
From the sphere survey, more than $1 / 2$ half of the respondents said there were no medical facilities within the cyclone shelter. Only $10 \%$ people were very satisfied about medical facilities. Almost $25 \%$ people were dissatisfied and $15 \%$ people were pleased on medical facilities. A large amount of people suffers from various diseases such as diarrhea, dysentery, fever, typhoid, cholera, skin diseases etc. during cyclones. But the medical facilities within the shelter are not good. There is no provision of emergency medical repair within the shelter. In most shelter doctor is not present. Only in Caritas and Heed Bangladesh manage one or two doctors. But it is extremely little for the people who take place within the shelter.

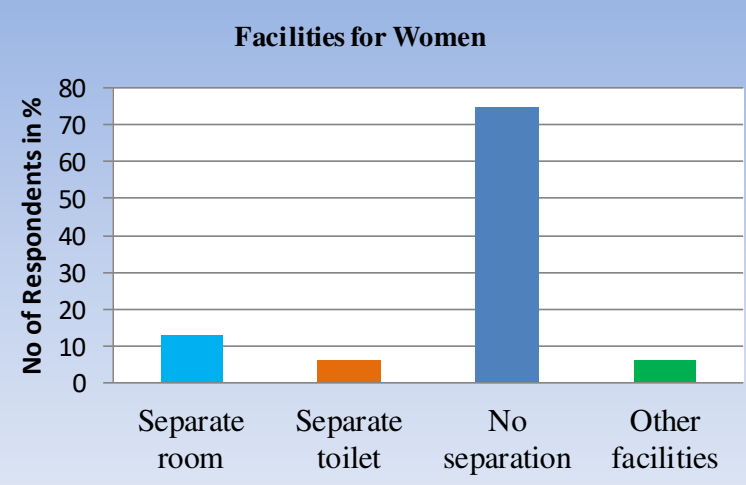

Fig 7: Facilities for women (Field Survey-2018).

4.10 Facilities for women - Women are more susceptible toward climate induced disasters (Cell, 2009). Women cope with continued deprivation and poverty during and in response to climatic disasters (Alam et $a l ., 2008)$. In the time of disaster women faced many problems. Separate room in the cyclone shelter is the most important facilities for women. But separate room is not available within the cyclone shelter (Fig 7). There were no separate amenities for ladies within the cyclone shelters almost $75 \%$ people said. Only 13 $\%$ people said about separate room for ladies within the cyclone shelter. Almost $6 \%$ people said about separate toilet facilities and other facilities for ladies within cyclone shelter. About 1/2of the populations within the study region are women. The female member of the relatives rejects to travel to cyclone shelters for their bad experiences from the olden times. Within the cyclone shelter woman faces sexual harassment at the same time theft and robbery. Gender sensitive cyclone shelters should be designed to UniversePG I www.universepg.com eradicate the negative impacts on women (Chowdhury et al., 2015). Govt. policies and institutional frameworks can provide proper security against women vulnerability.

4.11 Special facilities for pregnant women - Pregnant women are also vulnerable within the moment of disaster. Regarding1/2of the populations are women with-in the study region. But there were no special facilities for pregnant women (Fig 8). Now a day it is a great issue special facility for pregnant women within the shelters.

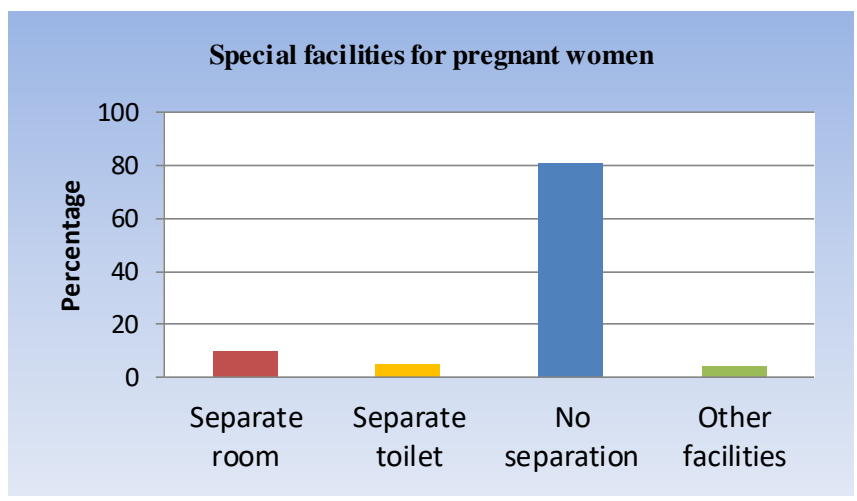

Fig 8: Special facilities for pregnant women (Field Survey-2018).

Almost $81 \%$ people said there were no separation facilities for pregnant women within the shelters. $10 \%$ people said about separate space designed for pregnant women. Only $5 \%$ respondent said about toilet facilities in the cyclone shelter designed for pregnant ladies. $4 \%$ said about other facilities for pregnant ladies. During field visit it had been found that several abortion and miscarriages occur owing to not availableness of separate area and for walking long distance to achieve cyclone shelters.

4.12 Overall facilities of cyclone shelter - Overall amenities of shelter are negligible (Fig 9). It is originated that here is no arrangement for the disable or handicap people either inside the shelter or lifting to the shelter. But this is necessary to maintain the facilities within the shelters to save the life of disable people during disaster. In study area, drinking water facilities was $33 \%$ within the shelter, sanitation facileties $25 \%$, medical facilities $12 \%$, facilities for ladies $13 \%$, special facilities for pregnant women $10 \%$, other facilities $7 \%$. Overall facilities within the shelter were very poor rather than people expectation. 


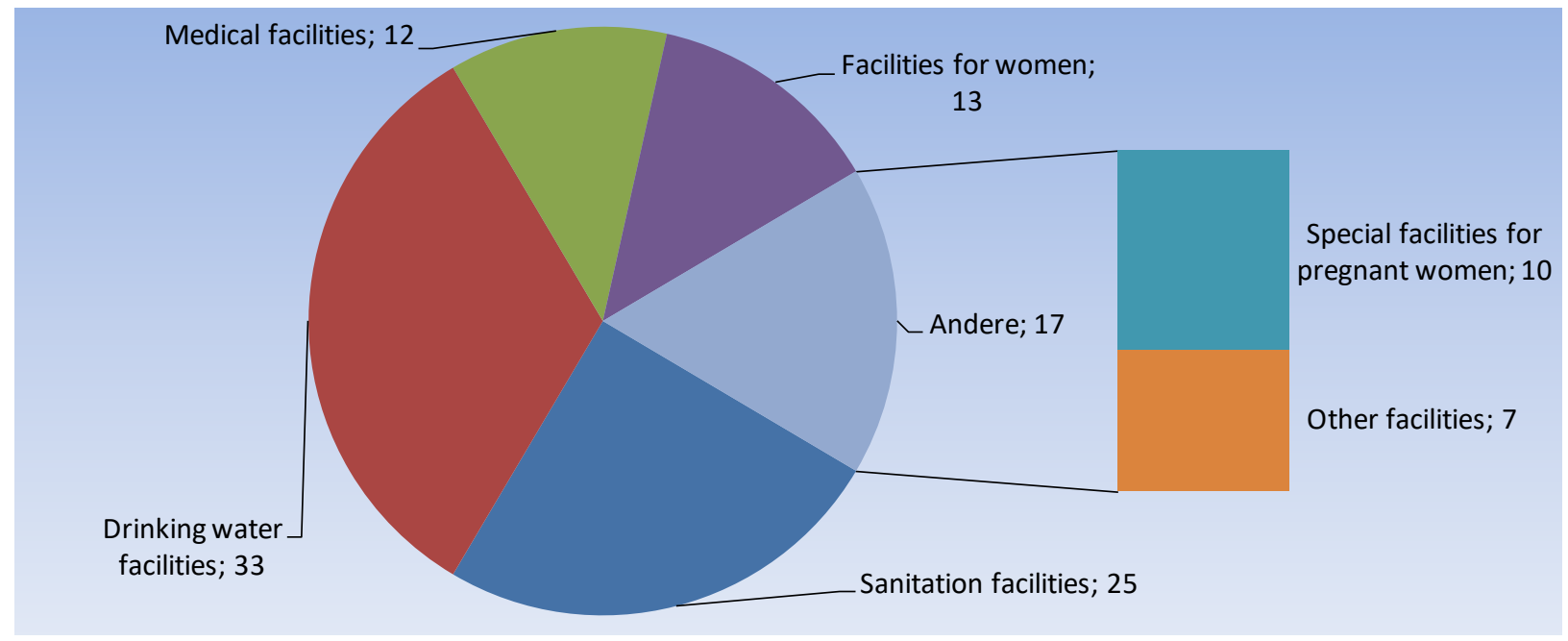

Fig 9: Overall facilities of cyclone shelter (Field Survey-2018).

4.13 Problems of cyclone shelters - In the moment of disaster People faces many problems within cyclone shelter. Violence, overcrowded, harassment and insecurity are major than others (Fig 10).

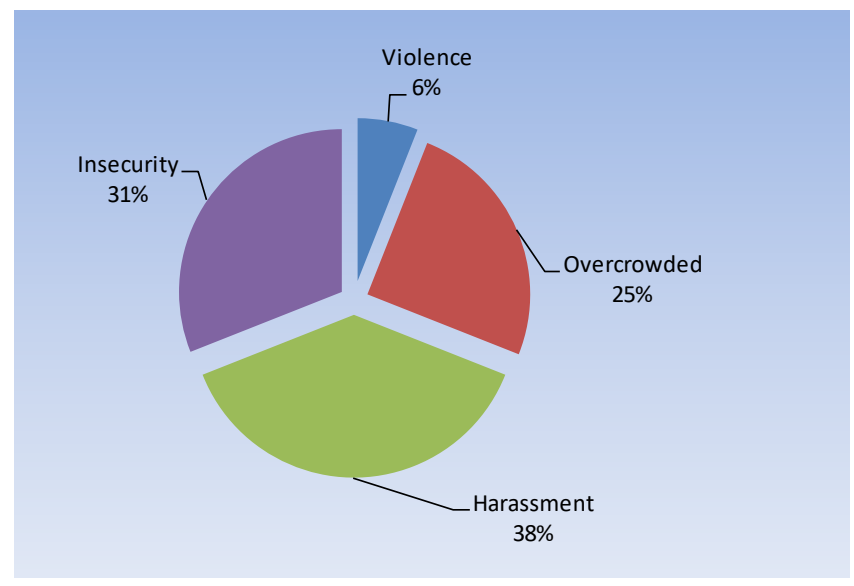

Fig 10: Other problems of cyclone shelters (Field Survey-2018).

Almost $38 \%$ public of the lessons area said about harassment problem within the shelter. $31 \%$ people said they feel insecure within the shelter. They lost their most valuable thing and money within the shelters. All time they pass their time in frustration. Within the study region $25 \%$ people said about overcrowded problem. Only $6 \%$ people about violence problem within the shelters. Problems of cyclone asylum reduce the no of interested people about goes to cyclone shelter.

4.14 Overall problems of shelters - Within study region a large amount of people is faced sanitation problem within the shelter. A large amount of cyclone UniversePG I www.universepg.com shelters was extremely much unhealthy about sanitation. Drinking water availability was less rather than people's demand. Medical facilities were not accessible within the shelter for the affected people. Capacity of shelters is poor compare to the total residents of the study region. Capacity problem is a great problem within this area. A large amount of cyclone shelters is not adequate to divide room facilities designed for man and women (Chowdhury et al., 2015).

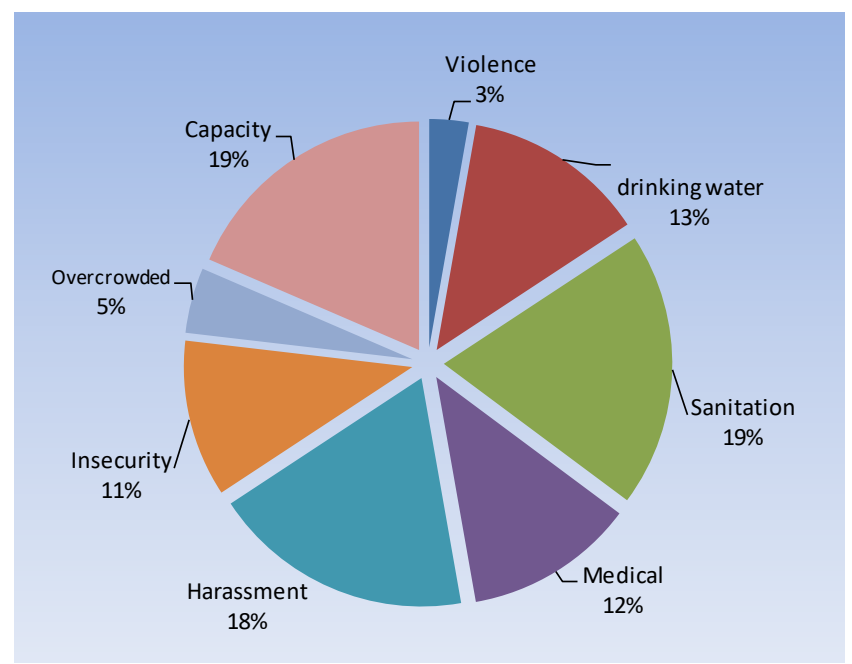

Fig 11: Overall problems of cyclone shelter (Field Survey-2018).

Basic gender needs like separation toilet facilities, available women's space and special space for pregnant woman and nursing's mother. These facilities are rare in the cyclone shelters. Lack of women space is a reason for women harassment. A large number of cases sexual harassment occurs for these problems. Overcrowded and violence was also seen as a problem 
in the cyclone shelters. A notable number of women face sexual harassment as well as theft and robbery. Overall problems of cyclone shelters are given away at below (Fig 11). During disaster most ladies and girls have suffered some form of violence in or throughout their lives. The substantial also emotional violence occurs within the families and in the flood as well as cyclone shelters (Rahman, 2013). The crowded shelters had an upper median daily frequency of sleep disturbance compare toward the non-crowded shelters (Kawano et al., 2016). Concentration must be paid to the various needs and priority of people.
4.15 Major initiative require to be taken to solve those problems - From the people's perception a good number of people realized that available training program require to be taken to solve the problems. Awareness rising is an essential part to aware people about cyclone shelter uses. Education is necessary for every people. When people are being educative the majority of peoples aware about problems and they obtain required steps to reduce the problems. From the people's perception major initiatives are training programs, awareness rising, enhancing management system, involve people as a volunteer and education (Fig 12).

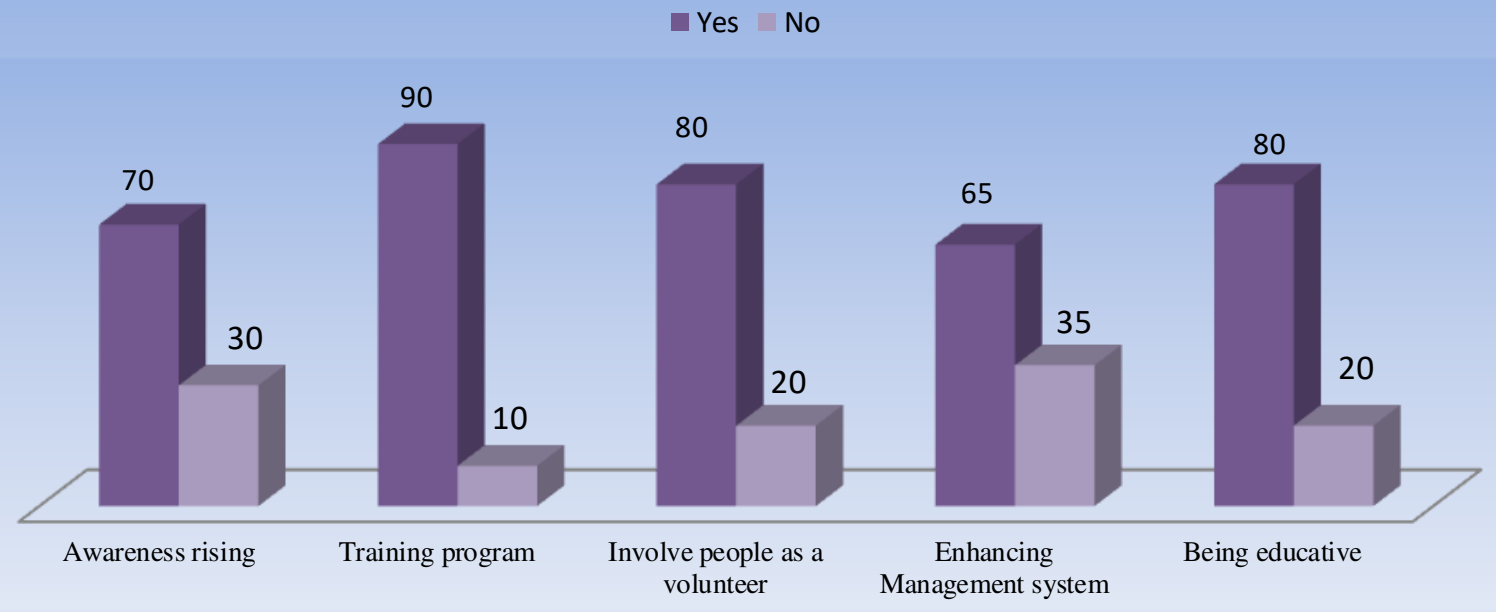

Fig 12: Major initiatives need to be taken to solve those problems (Field Survey-2018).

From the field survey about $70 \%$ people said, they need awareness raising program about cyclone and cyclone warning. Moreover, $90 \%$ people said about training program. While $80 \%$ people suggest involve people as a volunteer to decrease the problems. About $65 \%$ people said about enhancing management system. Whereas, $80 \%$ people said proper education can reduce the problems. When management committee must acquire required steps about management system that times many problems will be reduced.

4.16 Dissemination system of warning among community - Within the study region a large amount of people received disaster warning by hand mike (Fig 13). Electricity is a problem to disseminate warning among community in the moment of disaster. The reasons for not receiving warning messages by the rest of the respondents were: (a) lived in remote areas, therefore could not be reached by megaphones or hand mike and/or (b) did not have access to radio or television. Community is not able to recognize the warning. Early warning is a concern issue in disaster management field.

About $56 \%$ people said they received warning by hand mike. Almost $25 \%$ respondents said they received warning via the confined authority. Radio or $\mathrm{TV}$ is way to disseminate warning in the moment of disaster. But within the study region only $13 \%$ people received warning by radio or TV. $6 \%$ people said they received warning by mobile phone. More than half of the citizens were dissatisfied about receiving of early forewarning. Only $20 \%$ people were please degrading early warning system. Almost $16 \%$ people had no explanation about receiving early warning. Illiteracy, lack of awareness, receiving of warning and communication problems means that some people do not realize or follow the warnings. 

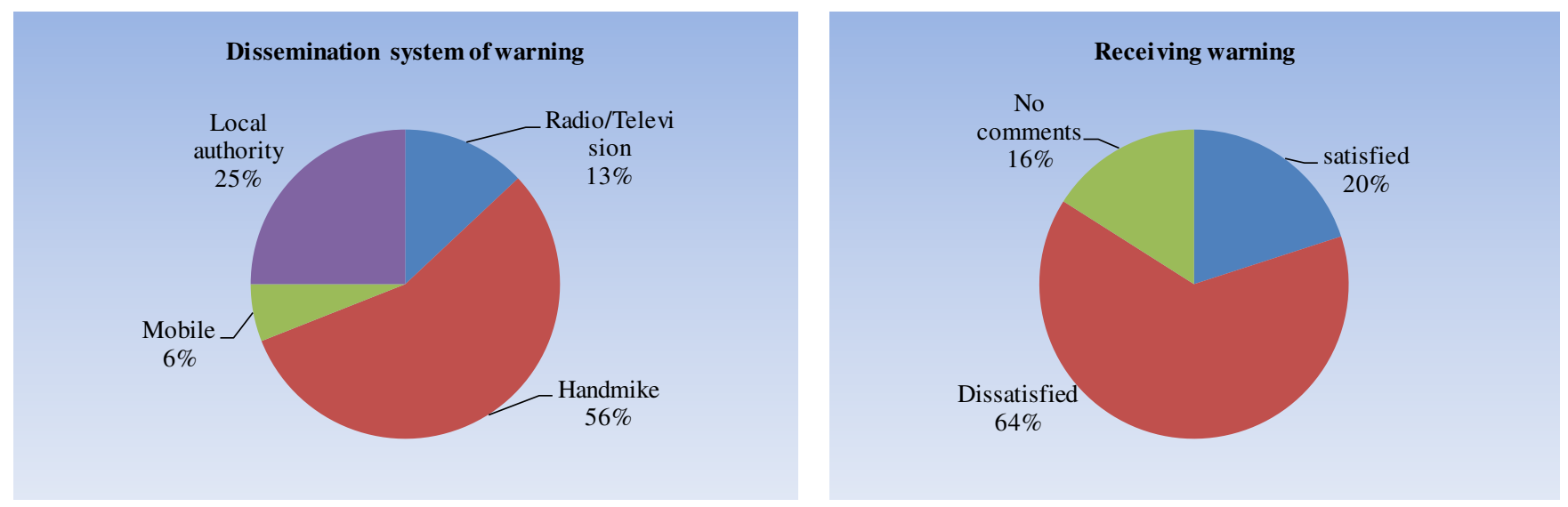

Fig 13: Broadcasting of warning and receiving warning among people (Field Survey-2018).

In study area many people are do not understand the warning. Sometimes vulnerable communities do not receive an early forewarning due a require of partnerships and transportation (Bisson, 2012). Bangladesh is now totally enclosed by mobile phone telecommunication networks; issuing cyclone for earning post through mobile phones is consequently a good option.

\subsection{Management system of cyclone shelters -} Overall concern for management of shelter is including with physical facility and human resources (Shelters and shelter management, 2005). From the field investtigation, it is found that a large amount of cyclone shelters has no management systems (Fig 14). Shelter manager duties and responsibilities are many. But many shelters have no shelter manager. To provide essential elements designed for the citizens every shelter must be maintained with proper management system. Within the study region people are very much poor. Proper management associated with some works such as Pick up and transport persons to designated shelter, identify welfare needs, provide counseling and reassurance, remove debris to keep access open, Check shelter for fire safety, provide medical treatment where necessary, Check water supply for quantity and quality, Maintains records on health problems, Check toilets for condition and proper use. Management systems of shelter are not good in the study region.

Almost $70 \%$ people said that there was no management system within the shelters. Almost $20 \%$ people were very dissatisfied about supervision system of shelters. Almost $10 \%$ people were pleased about supervision system of shelters. Meetings with the shelter management staff at regular intervals are UniversePG I www.universepg.com crucial to the success of shelter operation. Duties and specific tasks could be allocated to members (Shelters and shelter management, 2005).

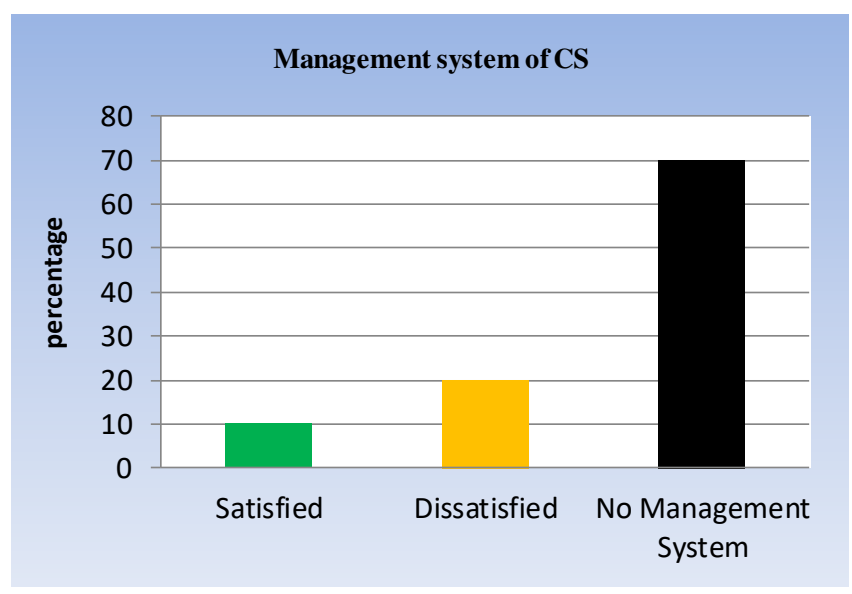

Fig 14: Management system of cyclone shelter (Field Survey-2018).

4.18 Training Facility about cyclone, cyclone shelter usability as well as management - Within study area almost $75 \%$ respondents said they not receive any training about cyclone, cyclone shelter usability and management (Fig 15). Only $25 \%$ people said they receive training for different organizations.

More than $1 / 2$ of the citizens said training program was insufficient for them. Training program is essential for all public. But training facility was not proper rather than people expectation. A large amount of people is interested to travel to training. Peoples are realizing, training program is very much effective for enhancing community resiliency to disaster. Almost $30 \%$ people said training program was sufficient for them. $20 \%$ people had no comments about training. 


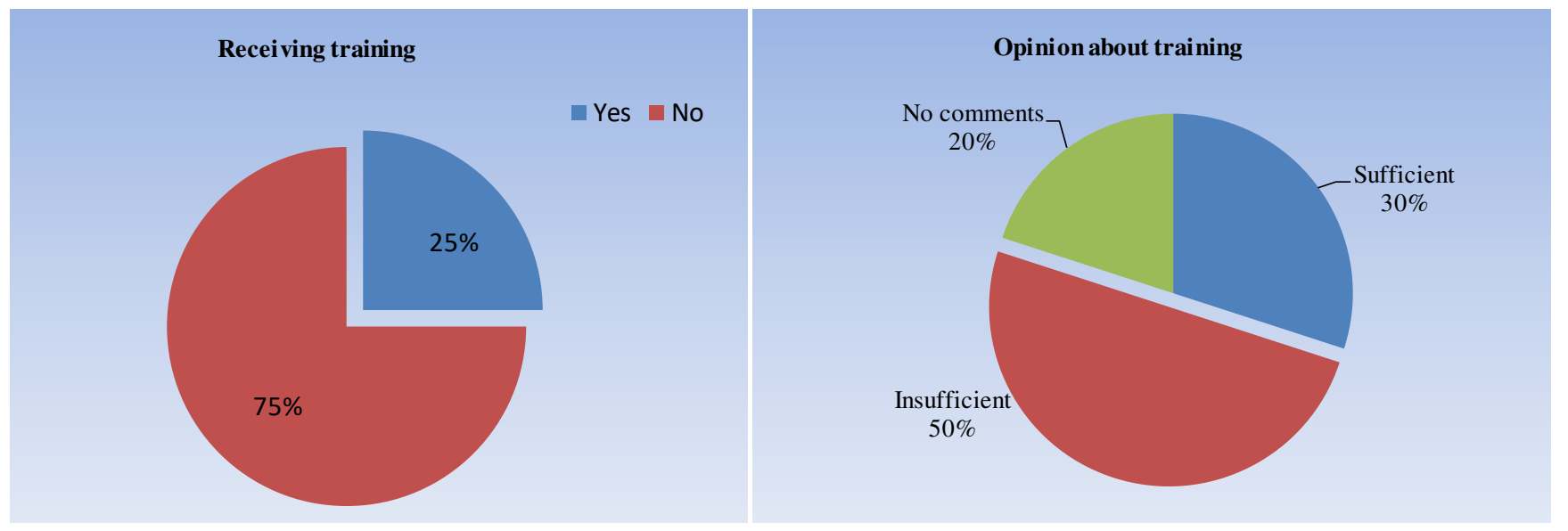

Fig 15: Receiving and opinion about training (Field Survey-2018).

4.19 Training program organized by different organizations - Local government engineering department organized many training under the project $\mathrm{CC}$ RIP. Within the study region almost $55 \%$ training conducted by LGED (Fig 16). South Asia Partnership (SAP)-Bangladesh is a national level NGO devoted to promote the socio-economic condition of the poorer section of the population in Bangladesh. Within the study area $10 \%$ training conducted by SAP Bangladesh.

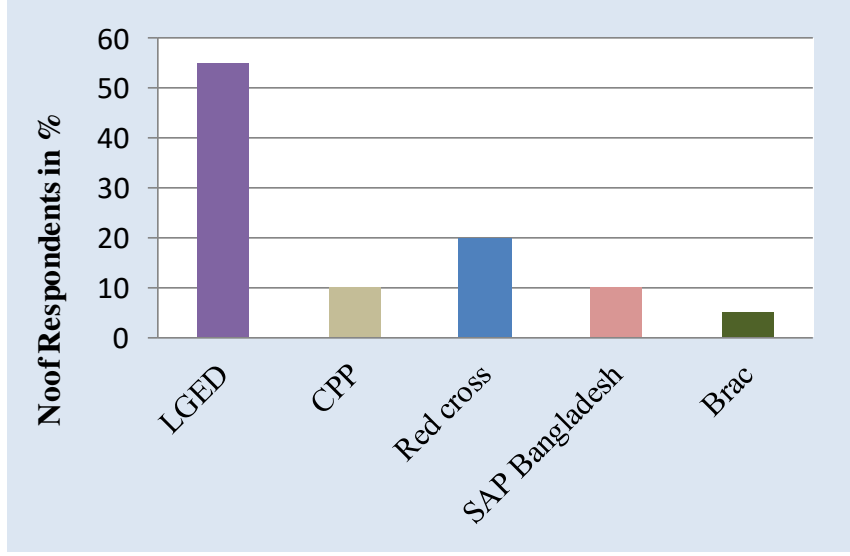

Fig 16: Government and non-government organization provide training among people.

Cyclone preparedness program (CPP) arranged $10 \%$ training in the study region. Red Cross is also cooperating a function to train people about disaster. 20 $\%$ training is conducted by Red Cross. Almost $5 \%$ training are conducted by Brac. Training program is so much poor rather than expectation. The non-governmental organization Red Crescent encompasses a long tradition of training communities on disaster risks, increasing safety and resilience through campaigns, informal education, democratic learning and formal school-based interventions.

\section{CONCLUSION AND RECOMMENDATION:}

This study has been accomplished to identify the cyclone shelter facilities ad limitations. Cyclone Shelters is extremely essential to support people from the cyclonic disaster. But cyclone shelters within the study region were not properly designed, maintained and facilitated. A large number of respondents said services of cyclone shelter were not acceptable level. After completing the study author found that $65 \%$ respondents said shelters are not available in their area. Distance of the cyclone shelter is moreover a fact for the unwillingness of the people. According the field investigation $14 \%$ people said no sanitation, 64 $\%$ said about unhealthy sanitation. Only $31 \%$ people said water facility (deep tube well) are available within the shelter. Medical services of the shelter also negligible. $50 \%$ said there were no medical facilities. Facilities for women and expecting women are also a concern issue. But the majority of cyclone shelters have no facilities for them. Insecurity, harassment, capacity problem is found in the study region. Early warning method is not good in the study area. Only 20 $\%$ people were satisfied about early warning broad casting system. Almost $70 \%$ people said about no management system within the shelters. Only $10 \%$ people said they are satisfied about management system. Facilities should be available for increasing citizen's numbers to acquire shelter. To overcome from the constraint awareness raising program, training program, involve people as a volunteer, enhance- 
ing management system and proper education should be needed for all people. People are attracted to travel to cyclone shelters when all facilities are available in the cyclone shelter.

From overall observation, discussion and analysis; the following recommendations are made for remedy of the problems and to develop the facilities of cyclone shelter:

$>$ Construction of cyclone shelter should be in proper design and distance from the group of people.

$>$ Increase no of cyclone shelter as well as capacity should be considered rather than population

$>$ Sanitation services of the cyclone shelter should be hygienic. Sanitary supplies such as toilet paper, napkins, soap, feminine hygiene supplies also should be accessible within the shelters.

$>$ Mineral water must be stored for the people as well as take some initiatives to enhance the rain water harvesting for safe drinking water.

$>$ Government as well as non-governmental organization should take some actions designed for the health services, facilities for women and pregnant women.

$>$ Special initiatives should take for the rural and illiterate people such as colorful warm sky balloon can be used to transfer cyclone-warning messages in inaccessible and coastal areas

$>$ Proper education and awareness raising program can minimize the harassment problem, violence, overcrowded and insecurity problems within the shelter.

$>$ Training program should be available for all people. Training module should be including with cyclone, cyclone shelter usability and cyclone shelter management

\section{ACKNOWLEDGEMENT:}

We want to express our deep gratitude and acknowledgement to the local government engineering department office (LGED), Barguna, Bangladesh and to the faculty of environmental science and disaster management of Patuakhali Science and Technology University for facilitating this research. We would like to especially thank the cordial, hospitable and co- operative participants of this research for their time and efforts where the questionnaires were administered and without whom this research would not have been possible. Some other people also helped us at different stages of this research. Thanks also to the reviewers for their constructive comments and valuable suggestions.

\section{CONFLICTS OF INTEREST:}

The authors declared no possible conflicts of the interest with respect to the research, authorship and publication of this article.

\section{REFERENCES:}

1) Ahmed, A.U., (2010). Reducing vulnerability to climate change: the pioneering example of community-based adaptation in Bangladesh. Center for Global Change (CGC) and CARE Bangladesh, Dhaka, p.156.

2) Ahamed, S., Rahman, M.M. and Faisal, M.A., (2012). Reducing cyclone impacts in the coastal areas of Bangladesh: A case study of Kalapara Upazila. J. Bangladesh Inst. Plan, 2075, p.9363. https://www.bip.org.bd/SharingFiles/journal book/ 20130804140921.pdf

3) Alam, K., Fatema, N., Bashar, W. and WEDO (Women's Environment and Development Organization), (2008). Case Study: Gender, Human Security and Climate Change in Bangladesh. Gend., Clim. Chan. and Hum. Security, pp.47-57.

4) Amin, M. N., Shil, S. C., \& Hasan, M. (2016). Status of cyclone shelter facilities in south central Bangladesh. Journal of Environmental Science and Natural Resources, 9(1), 75-79. https://doi.org/10.3329/jesnr.v9i1.30295

5) BBS, (2011). Population and Housing Census 2011 Bangladesh Bureau of Statistics and Informatics Division Ministry of Planning, Version 1 (March 2014). https://catalog.ihsn.org/index.php/catalog/4376

6) Bisson, T., (2012). An assessment of cyclone mitigation and management policies of Bangladesh: A focus on early warning systems.

7) Cell, C.C., (2009). Climate change, gender and vulnerable groups in Bangladesh. DoE, MoEF, Component 4b, CDMP, MoFDM, Dhaka, pp.182. https://core.ac.uk/download/pdf/48024281.pdf 
8) Choudhury, S. A., (2014). Country Report of Bangladesh on Effective tropical cyclone warning in Bangladesh, pp. 2-12.

https://www.jma.go.jp/jma/jma-eng/jma-center/rs mc-hp-pub-eg/2014 Effective TC Warning/cr/c ountry_report Bangladesh(1).pdf

9) Chowdhury, M., Jisan, M. A. Kabir, R., Hail. \& Hossain J., (2015). A Study of Cyclone Shelters in the Coastal Bangladesh: an Assessment from Gender Perspective, Retrieved April 15, 2017.

10) Dasgupta, S., Huq, M., Khan, M.F. and Pandey, K., (2014). Cyclones in a changing climate: the case of Bangladesh. Climate and Development, 6(2), pp.96-110. https://doi.org/10.1080/17565529.2013.868335

11) DMB, (2010). National Plan for Disaster Management 2010-2015, Disaster Management \& Relief Division, Government of the People's Republic of Bangladesh.

12) Hasan, M.T., (2008). Surviving cyclones: the indigenous wisdom. Unnayan Onneshan, Dhanmondi, Bangladesh. https://www.eldis.org/document/A60362

13) Karim, N., (2006). Options for cyclone protection: Bangladesh context. Climate Institute, 6.

14) Kawano, T., Morita, H., Hiraide, A. and Hasegawa, K., (2016). Association between shelter crowding and incidence of sleep disturbance among disaster evacuees: a retrospective medical chart review study. BMJ open, 6(1), pp. 1-7. https://www.ncbi.nlm.nih.gov/pmc/articles/PMC47 $\underline{35147 /}$

15) Mahmood, M.N., Dhakal, S.P. and Keast, R., (2014). The state of multi-purpose cyclone shelters in Bangladesh. Facilities, 32(9/10), 522-532. http://www.networksandcollaborations.com.au/files /Facilities.pdf
16) Nasreen, M., Hossain, K.M. and Azad, M.A.K., (2013). Climate Change and Livelihood in Bangladesh: Experiences of people living in coastal regions, Proce. Of Int. Con. of Building Resilience, pp.1-25.

17) Obaidullah, A.K., (2014). Vulnerability, Risk and Climate Adaptation in the Coastal Area of Bangladesh (Doctoral dissertation, Universität Hamburg, School of Integrated Climate System Science (SICSS) Hamburg).

18) Rahman, M.S., (2013). Climate change, disaster and gender vulnerability: A study on two divisions of Bangladesh. American Journal of Human Ecology, 2(2), pp.72-82. https://doi.org/10.11634/216796221504315

19) Rasheduzzaman M, Uddin A, Shamsuzzoha M., and Rahman MA. (2020). Analysis of cyclone shelter patterns to build a better shelter management: a case study of Bangladesh southern region, Asian J. Soc. Sci. Leg. Stud., 2(3), 47-55. https://doi.org/10.34104/ajssls.020.047055

20) Roy, C., Sarkar, S.K., Åberg, J. and Kovordanyi, R., (2015). The current cyclone early warning system in Bangladesh: providers' and receivers' views. International journal of disaster risk reduction, 12, pp.285-299.

https://www.diva-portal.org/smash/get/diva2:8122 10/FULLTEXT01.pdf

21) Shelters and Shelter Management Reference Guide, (2017). Retrieved April 12, 2017.

22) Tamima, U., (2009). Population evacuation need assessment in cyclone affected Barguna district. Journal of Bangladesh Institute of Planners, 2, pp.145-157. https://doi.org/10.3329/jbip.v2i0.9575

Citation: Nur MNB, Rahim MA, and Rasheduzzaman M. (2021). Identifying cyclone shelter facilities and limitations for enhancing community resiliency in coastal areas of Bangladesh, Asian J. Soc. Sci. Leg. Stud., 3(4), 107-118. https://doi.org/10.34104/ajssls.021.01070118 (c) () 